\title{
THE MORFOMETRICS CHARACTERICS AND CONDITION INDEX OF AUSTROPOTAMOBIUS PALLIPES IN THE NERETVA RIVER BASIN
}

\section{Morfometrijske karakteristike i kondicioni indeks Austropotamobius pallipes iz sliva rijeke Neretve}

\section{Sadbera Trožić-Borovac ${ }^{1}$, Armin Macanović1 ${ }^{\text {, Rifat Škrijelj }}{ }^{1}$}

\begin{abstract}
Specimens of white-clawed crayfish have been cought during from May to August 2011. The specimens were fished out from the tributaries of the river Neretva: Neretvica, Sistica and Kraljuscica. The study was done on $100 \mathrm{~m}$ of waterstream, where an unequal numbers of individuals was determined. 31 individuals was found in river Neretvica, 10 individuals in river Sistica and 4 in river Kraljuscica. Different hydromorphological characteristics of the waterstream have largely contributed to the different population abundance of this crayfish. Morphometric analysis included six parameters: (TL) total length $[\mathrm{cm}],(W)$ weight (gr), (ARL) carapace length $[\mathrm{cm}]$, $(\mathrm{CPW})$ carapace width $[\mathrm{cm}],(\mathrm{ROL})$ rostrum length $[\mathrm{cm}],(\mathrm{ROW})$ rostrum width $[\mathrm{cm}]$, (CLL) claws length [cm] and (TEL) tail length [cm]. Total body length of the whiteclawed crayfish varied from 4.3 to $8.6 \mathrm{~cm}$, while the individual with maximum length was found in river Neretvica. Weight of the individuals varied from $5 \mathrm{~g}$ to $26 \mathrm{~g}$. Weight is the parameter with the highest coefficient of variation where differences in weight were found in the individuals of equal length. According to the shape (length and width) of the rostrum, crayfish from river Neretvica and Kraljuscica had higher similarity than recripocally than with the individuals cought in river Sistica (isosceles triangle). The connection between body length and carapax width had been determined by linear regression, as well as the connection between body length and claws length. Condition index values are higher in males than in females and the male domination was express in all three watercourses, as well as in the overall sample (28males and 17 females).
\end{abstract}

Key words: crayfish, autochthonous, relation of sexes, weight, rostrum shape, regression, correlation.

\footnotetext{
${ }^{1}$ Faculty of Natural Sciences and Mathematics
} 


\section{INTRODUCTION - Uvod}

The white-clawed crayfish, Austropotamobius pallipes (LEREBOULLET, 1858) is the oldest species in family Astacidae. In tertiary (Miocene), there were no barriers such as Alps and Pyrenees, and this species had spread on all Europe in freshwater ecosystems (MAGUIRE, 2004). Freshwater crayfish from Astacidae family, although being partially protected by law, still haven't been explored sufficiently in Bosnia and Herzegovina. In the area of Bosnia and Herzegovina there are some data of Astacidae (EnTZ, 1914; Karaman, 1929; Karaman, 1961; Karaman, 1962; Karaman, 1963; AlBRECHT, 1983; TROŽIĆ-BOROVAC et al... 2007; ŠANDRA AND PETRUŠEK, 2008; TROŽIĆBOROVAC, 2011; TROŽIĆ-BOROVAC, 2012), but insufficiently is still known on their biology, ecology, countability and distribution.

Nowadays, natural distribution of Astacoidea and Parastacoidea have been changed in many countries. Under human impact many auchtonous species moved to other watercourses even other continents with purpose of aquaculture or introduction due to „enriching“auchtotonous fauna (GHERARDI AND HOLDICH, 1999). Alochtonous species are very often, very adaptable and some are extremely invasive, being spread quickly and once introduced in area they extrude auchtotonous species, and they become rare (TAYLOR, 2002).

Within the territory of Bosnia and Herzegovina A. pallipes is predominantly present in the Neretva River basin, partly in the Una River basin and in the Cetina River basin (TROŽIĆ-BOROVAC, 2011, TROŽIĆ-BOROVAC, 2012).

In its distribution, this species was recorded at altitudes from $180 \mathrm{~m}$ to 1204 $\mathrm{m}$., but the largest number of locations are at altitudes from 300 to $600 \mathrm{~m}$. The water temperature measured in the period of sampling varied form $10^{\circ}$ to $20^{\circ} \mathrm{C}$. Saprobity index determined according to the composition of macroinvertebrates and phytobenthos (plankton in lakes) indicates that it is present in clean and slightly polluted waters (TROŽlć-BOROVAC, 2011).

Although all representatives of Astacidae Latreille, 1802 family have common basic morphological characteristics, however thanks to different habitats, specific characteristics developed by which they differ. (HOLDICH, 2002). Research starting point was significance of white clawed crayfish in overall fauna diversity of certain area and in definition of autochthonous species and its degree of conservation.

The aim of this paper is to determine the values of morphometric characters of the white-clawed crayfish in the researched watercourses, to analyze conditionality of the parameters, to determine the degree of similarities/differences of the individuals from different habitats and to point to the needs of long-term studies whose primary goal wll be adequate legal protection of habitat for this, already, endangered species. 


\section{MATERIALS AND METHODS-Materijal i metode rada}

Locations where white clawed crayfish over fishing took place were analyzed from the ecology aspect, coastal and water vegetation were analyzed as the sediment and water quality. Photographs of the locations were taken and GPS coordinates defined.

Adriatic Sea catchment includes area of south and southwest part of Bosnia and Herzegovina. Its surface is $12410 \mathrm{~km}^{2}$ or around $30 \%$ territory of Bosnia and Herzegovina. River Neretva is only Adriatic tributary which penetrates to the sea by its surface as a difference to the underground river where Trebišnjica is the highest.

Neretva is the longest and richest in water and tributary of Adriatic Sea in the Balcan penninsula. It is emerging at $1.227 \mathrm{~m}$ above sea level, under peak, which belongs to the spurs of mountain Lebršnik. Water course length is $238 \mathrm{~km}$, where 218 km runs through Bosnia and Herzegovina (VARIŠčIĆ, 2009). Upstream Neretva runs through valley that spreads parallel with mountain massive and it doesn't intersect it. Through its watercourse, various profile change from cliff-canyon shape with higher or lower slope up to big expansions.

Locations were crayfish were caught are on various geographic positions. Rivers Neretvica and Kraljušntica are right tributaries and Šištica is left tributary of river Neretva (figure 1). These rivers are considerably canyon rivers in their flow and with bigger river bed falls.

Climatogene communities of broader area belong to sub Mediterraneanmountain area.

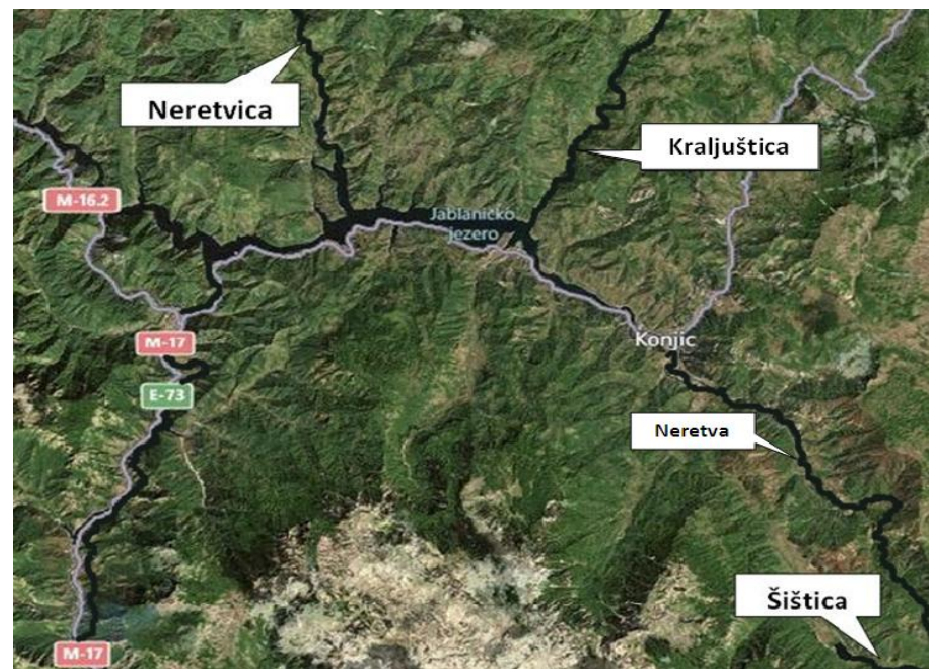

Figure 1 Satellite image of the researched area (Neretva catchment area), with marked locations (taken from http://globalearthmaps.blogspot.com/)

Slika 1. Satelitski snimak istraživanog područja (sliv Neretve), sa naznačenim lokalitetima (preuzeto sa http://globalearthmaps.blogspot.com/) 


\section{$\underline{\text { River Neretvica }}$}

GPS coordinates of the locations: $43^{\circ} 45^{\prime} 31.38^{\prime \prime} \mathrm{N}$ and $17^{\circ} 48^{\prime} 26,40^{\prime \prime}$, altitude $295 \mathrm{~m}$.

River Neretvica springs beneath Vitreusa peak, that is on the slopes of mountain Zec, on altitude of $1915 \mathrm{~m}$. Neretvica is bifurcating in valley so these waters contribute to the cooling of the environment. River is of a rapid mountain stream character with cascades and quick flow. It is bordered with thick vegetation consisted of alder trees (Alnus glutinosa Gaertn) and bush-like plants. River bed width is between 6 and $8 \mathrm{~m}$, while the bank height is around $90 \mathrm{~cm}$. At the researched area, river depth was between $20-60 \mathrm{~cm}$ (figure 2).

\section{River Kraljuščica}

GPS coordinates locations: $43^{\circ} 42^{\prime} 26,27^{\prime \prime} \mathrm{N}$ and $17^{\circ} 54^{\prime} 54,78^{\prime \prime}$ altitude $320 \mathrm{~m}$. River Kraljusntica springs in the area of mountain Bitovinja, descending with its water flow in width between 2 and $4 \mathrm{~m}$, up to the settlement Kralupi where it flows into Jablanicko lake. Watercourse of river Kraljuščica is typical mountain with uneven annual water flow. Watercourse depth on researched locations was between 30 and 60 $\mathrm{cm}$, bank height was around $25 \mathrm{~cm}$ (figure 2).. Precipitation regime is rain-snow which causes emergence of spring and autumn maximum as the summer and winter minimum. Sediment is megalithal with $70 \%$, and akal (gravel) is represented with $30 \%$ (AQEM consortium, 2002).

\section{$\underline{\text { River Šištica }}$}

River Šištica research location is at 404 meters above sea level and GPS coordinates were: $43^{\circ} 33^{\prime} 2.25^{\prime \prime} \mathrm{N} 18^{\circ} 1^{\prime} 58.59^{\prime \prime}$ E. Šištica is a small river that arises from Boračko lake and runs through narrow cliff in length of $6 \mathrm{~km}$, and which deeply incises into surrounding rocks so in downstream it is very inaccessible, bank height was around $35 \mathrm{~cm}$. This watercourse is different compared to the others in terms of river bed which is smaller and less deep. River bed is $8 \mathrm{~m}$, and depth in period of research was 20 to $30 \mathrm{~cm}$ (figure 2).. Surrounding vegetation is consisted of mesophile meadows and alder trees, while downstream it gets character of canyon river. Sediment is represented by argilal and medium size stones (mesolithic).

Over fishing lasted 3 months (mey to august 2011), samples were over fished manually, measurements were conducted on the field and turned back to the water course from which they were taken, due to the extreme sensitivity of this specie and in order to avoid putting them in danger. 45 specimens of white clawed crayfish were fished. It was done in various period of day in order to spot the oscillations in distribution and in manifestation of this specie at the certain location. Research included rivers: Kraljuščica, Neretvica and Šištica. 

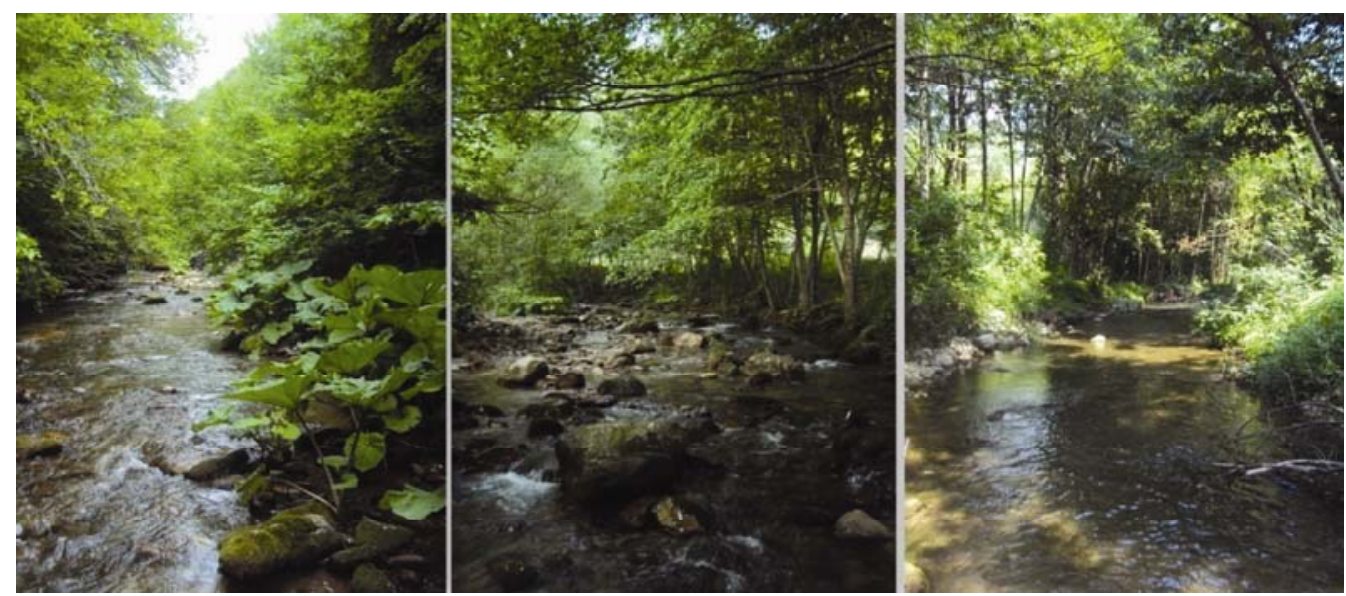

Figure 2. Researched watercourses: rivers Neretvica, Kraljuščica and Šištica (original photos) Slika 2. Lokaliteti istraživanja: rijeke Neretvica, Kraljuščica i Šištica

For each location presence and absence of crayfish were recorded and each animal was defined up to the specie. The white clawed crayfish were determined according to SOUTY-GROSSET ET AL. (2006).

Samples were taken manually with nets and hand made traps made of plastic bottles.

Upon sex determination and photographing sample is turned back to the water slowly in a such way that stomach is being on upper side, which enables that air that entered carapace gets out. In a case that crayfish isn't turned back to water this way there is possibility of crayfish dying. During measuring (figure 3) adequate tool is being used (caliper and scale), and parameters were selected being relevant for this specie (SINT at all., 2005)

Measuring was done by vernier caliper, length and width of individual parts is presented in centimeters, while weight is expressed in grams (g). All data are presented in tables. Upon terrain works and data collecting statistic processing and comparative analysis were conducted. 


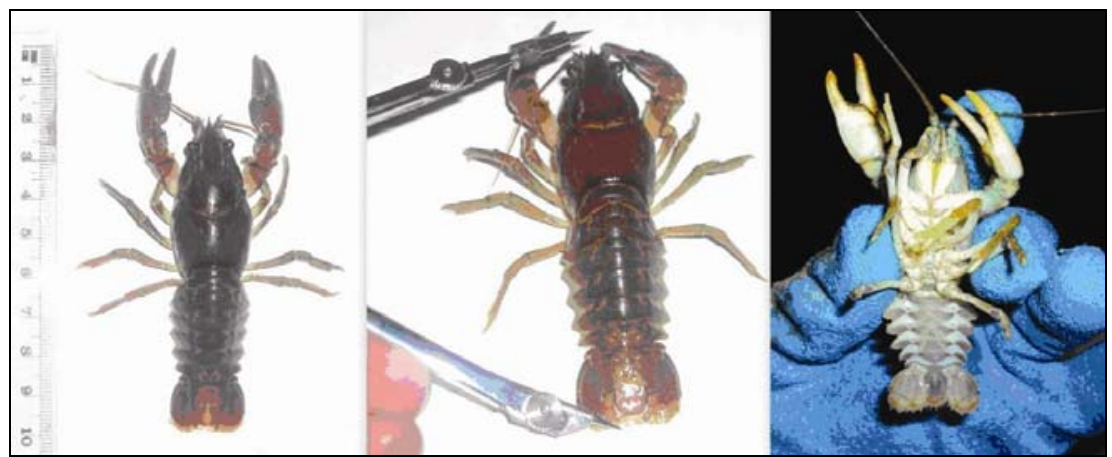

Figure 3. Presentation of white clawed crayfish Austropotamobius pallipes (Lereboullet, 1858) morfometric processing on terrain

Slika 3. Prikaz morfometrijske obrade bjelonogog raka Austropotamobius pallipes (Lereboullet, 1858) na terenu

\section{$\underline{\text { Data statistical analysis }}$}

Basic statistic data obtained as per Petz, 1985:

- $\quad$ Average value (arithmetic mean) $\bar{X}$

$\bar{X}=\frac{\sum X}{N}$

- $\quad$ Variance $\left(\mathrm{s}^{2}\right)$

$S^{2}=\frac{\sum(X i-\bar{X})}{N-1}$

- $\quad$ Standard deviation (SD)

$S D=\sqrt{S^{2}}$

Variability $<$ coefficient $(\mathrm{V} \%)$

$V_{\%}=\frac{100 \times S}{\bar{X}}$

Condition coefficient is calculated in two manners:

- $\quad$ Fulton's conditions factor (RICKER, 1975):

$F C T=W / T^{3}$

W-body weight, T-total body length

- $\quad$ Crayfish constant (ADEGBOYE, 1981):

$C C=W(T L \times A R L \times C P W)$

W-total weight, ARL-carapace length and CPW-carapace width (STREISSL \& HöLD, 2002). 
Regression analysis was used in order to determine the significance of linear relation of observed variables. Microsoft Excel and Statistica 8 were used, and in all statistic analysis $5 \%(p<0,05)$ significance level was used.

Data of physical-chemical parameters have been taken from the Institute of Public Health in Mostar with saprobic index values from the work "Biological monitoring of surface waters from the rivers Neretva and Cetina in the Federation of Bosnia and Herzegovina 2009-2012" Agency for the Adriatic sea river area FBiH Mostar.

\section{RESULTS-Rezultati istraživanja}

\section{Basic data on physical-chemical and biological analysis of researched locations.}

River Neretvica belongs to category I-II that is oligo up to beta mesosaprobic water, with saprobity index $(1,66)$,river Kraljuščica also belongs to category I-II with saprobity index value of $(1,70)$ while river Šištica belongs to category II beta mesosaprobic water with saprobity index value $(1,90)$ and temperature $11-15^{\circ} \mathrm{C}$.

Water temperature measured in researched watercourses of Neretva catchment area was in interval of 13,1 to $18^{\circ} \mathrm{C}$ (tab.1).

Table 1. Values of some physical/chemical water parameters and Saprobity index, in rivers Neretvica, Šištica and Kraljuščica

Tabela 1.Vrijednosti fizičko/hemijskih parametara i saprobnog indeksa vode rijeka: Neretve, Šištice i Kraljuščice

\begin{tabular}{|c|c|c|c|c|c|c|c|}
\hline Locations & Date & $\mathbf{p H}$ & $\left(\boldsymbol{\mu \mathbf { S c m } ^ { - 2 } )}\right.$ & $\begin{array}{c}\mathbf{O}_{\mathbf{2}} \\
\left(\mathbf{m g L}^{-1}\right)\end{array}$ & $\begin{array}{c}\mathbf{B P K}_{\mathbf{5}} \\
\left(\mathbf{m g L}^{-1}\right)\end{array}$ & $\begin{array}{c}\text { Temp. } \\
\left.\mathbf{(}^{\mathbf{0}} \mathbf{C}^{-1}\right)\end{array}$ & $\begin{array}{c}\text { Saprobity } \\
\text { index (S) }\end{array}$ \\
\hline Šištica & 15.08 .2002 & 7,8 & 220 & 10.3 & 1.80 & 18 & 1.90 \\
\hline Kraljuščica & 16.08 .2002$. & 7,7 & 313 & 11 & 0,85 & 16 & 1,70 \\
\hline Neretvica & 22.06 .2011$. & 8,3 & 220 & 12,01 & 0,61 & 13,1 & 1,66 \\
\hline
\end{tabular}

Morfometrics characteristics of white clawed crayfish Austropotamobius pallipes from river Neretva catchment area (rivers Neretvica, Kraljuščica and Šištica) Morfometrijske karakteristike bjelonogog raka Austropotamobius pallipes iz sliva rijeke Neretve (Neretvica, Kraljuščica i Šištica

In 3 researched tributaries of river Neretva 45 specimens of white clawed crayfish were defined, and Morfometrics measuring of character susceptible to the impact of environment was performed on them. Majority samples analyzed were from river Neretvica (31), minor from river Šištica (10) and least number of samples from river Kraljuštice (4). 
Measuring of following parameters were analyzed in details (tab.2): total length (TL), abdomen carapace length (ARL), carapace width (CPW), rostrum length (ROL), rostrum width (ROW), claws length (CLL), tail length (TEL) and body width (W). Results are presented in table together with average value $(\overline{\mathrm{X}})$.

Based on data statistics analysis and variability coefficient for measured samples of white clawed crayfish from river Neretvica, the highest variation was defined in body weight value $35,28 \%$ (tab.2).

Table 2. Morfometric characteristics of Austropotamobius pallipes in Neretvica River ( $\mathrm{n}=31$ ) Tabela 2. Morfometrijske karakteristike bjelonogog raka Austropotamobius pallipes (Lereboullet, 1858) iz rijeke Neretvice

\begin{tabular}{|l|r|r|r|r|r|}
\hline \multirow{2}{*}{$\begin{array}{l}\text { MORPHOLOGICAL } \\
\text { CHARACTERISTICS }\end{array}$} & \multicolumn{6}{|c|}{ BASIC STATISTICS DATA } \\
\cline { 2 - 6 } & Min. & Max. & $\overline{\mathbf{X}}$ & S & V\% \\
\hline (TL) total length (cm) & 4.3 & 8.6 & 6.8 & 1.12 & 17.23 \\
(ARL) carapace length & & & & & \\
(cm) & 0.7 & 1.6 & 1.2 & 0.24 & 21.8 \\
(CPW) carapace width & & & & & \\
(cm) & 0.9 & 2.9 & 1.8 & 0.49 & 27.2 \\
(W) weight (gr) & 0.5 & 26 & 14.2 & 5.01 & 35.28 \\
(ROL) rostrum length (cm) & 0.5 & 1.2 & 0.9 & 0.19 & 21.1 \\
(ROW) rostrum width (cm) & 0.5 & 0.8 & 0.7 & 0.08 & 11.4 \\
(CLL) claws length (cm) & 1.3 & 3.9 & 2.3 & 0.64 & 27.7 \\
(TEL) tail length (cm) & 0.7 & 1.4 & 1.1 & 0.2 & 18.1 \\
\hline
\end{tabular}

Analysis included 13 females and 18 mails, obtained data on average value of analyzed characteristics have higher value in female samples (tab.3).

Table 3. Comparative illustration of average values of selected characters of males and females of white clawed crayfish Austropotamobius pallipes in the river Neretvica

Tabela 3. Komparativni prikaz srednjih vrijednosti odabranih karaktera mužjaka $i$ ženki bjelonogog raka Austropotamobius pallipes iz rijeke Neretvice

\begin{tabular}{|c|c|c|c|c|c|c|c|c|}
\hline Gender & $\begin{array}{c}\text { Body } \\
\text { length } \\
\text { (cm) }\end{array}$ & $\begin{array}{c}\text { Carapace } \\
\text { length } \mathbf{( c m )}\end{array}$ & $\begin{array}{c}\text { Carapace } \\
\text { width } \\
\text { (cm) }\end{array}$ & $\begin{array}{c}\text { Body } \\
\text { weight } \\
\text { (gr) }\end{array}$ & $\begin{array}{c}\text { Rostrum } \\
\text { length } \\
\text { (cm) }\end{array}$ & $\begin{array}{c}\text { Rostrum } \\
\text { width } \\
\text { (cm) }\end{array}$ & $\begin{array}{c}\text { Claws } \\
\text { length } \\
\text { (cm) }\end{array}$ & $\begin{array}{c}\text { Tail } \\
\text { length } \\
\text { (cm) }\end{array}$ \\
\hline Female $(\mathrm{n}=13$ & 6.6 & 1.1 & 1.8 & 15.1 & 0.9 & 0.7 & 2 & 1.2 \\
\hline Male $(\mathrm{n}=18)$ & 7.8 & 1.4 & 2.1 & 22.4 & 1.1 & 0.7 & 2.7 & 1.2 \\
\hline
\end{tabular}

Body length and weight present significant differences and average rostrum width and tail length have same value (chart1).

In river Kraljuščica small population of white clawed crayfish was defined; 3 males and 1 female (tab.4).

Average body weight was $16,5 \mathrm{~g}$ while average value of body length was 7,3 $\mathrm{cm}$. The highest variability coefficient was determined in body weight and it was 17,6 , 
then body length 12,6 and rostrum length 8,7 . The lowest variation was in values of rostrum width with coefficient 6,3 . The lowest value of body length was determined in sample number 4 and it was $6,4 \mathrm{~cm}$ while the highest value was $7,9 \mathrm{~cm}$.

The highest value of carapace length was $1,4 \mathrm{~cm}$, and smallest carapace was $1,2 \mathrm{~cm}$. The lowest variation were in length of tail with variability coefficient 4,6 . The smallest value was $1,2 \mathrm{~cm}$ while highest was $1.3 \mathrm{~cm}$.

Table 4 Values of morfometrics characteristics of white clawed crayfish Austropotamobius pallipes from river Kraljuščica $(\mathrm{n}=4)$

Tabela 4. Vrijednosti morfometrijskih karakteristika bjelonogog raka Austropotamobius pallipes iz rijeke Kraljuščice

\begin{tabular}{|l|r|r|r|r|r|}
\hline \multirow{2}{*}{ MORFOMETRICS CHARACTERISTICS } & \multicolumn{5}{|c|}{ BASIC STATISTIC DATA } \\
\cline { 2 - 6 } & Min. & Max. & $\overline{\mathbf{X}}$ & \multicolumn{1}{c|}{ S } & \multicolumn{1}{|c}{ \% } \\
\hline (TL) total length (cm) & 6.4 & 7.9 & 7.3 & 0.63 & 12.6 \\
(ARL) carapace length (cm) & 1.2 & 1.4 & 1.3 & 0.1 & 7.7 \\
(CPW) carapace width (cm) & 1.6 & 1.9 & 1.8 & 0.15 & 8.3 \\
(W) weight (gr) & 14 & 19 & 16.5 & 2.08 & 17.6 \\
(ROL) rostrum length (cm) & 0.6 & 0.8 & 0.7 & 0.82 & 8.7 \\
(ROW) rostrum width (cm) & 0.7 & 0.8 & 0.8 & 0.05 & 6.3 \\
(CLL) claws length (cm) & 1.4 & 1.6 & 1.6 & 0.1 & 6.5 \\
(TEL) tail length (cm) & 1.2 & 1.3 & 1.2 & 0.005 & 4.6 \\
\hline
\end{tabular}

10 samples were caught in river Šištica that hade been morfometrically analyzed. The longest measured sample was $8.2 \mathrm{~cm}$ while the shortest was $6.1 \mathrm{~cm}$. Body weight of analyzed samples was in range from 13 to $20 \mathrm{~g}$ (tab.5).

Table 5 Morfometric characteristics of Austropotamobius pallipes in Šištica River $(\mathrm{n}=10)$ Tabela 5. Morfometrijske karakteristike bjelonogog raka Austropotamobius pallipes iz rijeke Šištice

\begin{tabular}{|l|rrr|r|r|}
\hline \multirow{2}{*}{$\begin{array}{c}\text { MORFOMETRIC } \\
\text { CHARACTERISTICS }\end{array}$} & \multicolumn{5}{|c|}{ BASIC STATISTIC DATA } \\
\cline { 2 - 6 } & Min. & Max. & $\overline{\mathbf{X}}$ & \multicolumn{1}{c|}{ S } & V\% \\
\hline (TL) total length (cm) & 6.1 & 8.2 & 7.3 & 0.82 & 11.5 \\
(ARL) carapace length (cm) & 1.0 & 1.4 & 1.3 & 1.43 & 11.2 \\
(CPW) carapace width (cm) & 1.8 & 2.1 & 1.9 & 1.08 & 5.1 \\
(W) weight (gr) & 13 & 20 & 16 & 2.21 & 14 \\
(ROL) rostrum length (cm) & 1.0 & 1.3 & 1.1 & 1.07 & 8.7 \\
(ROW) rostrum width (cm) & 0.6 & 0.8 & 0.7 & 0.63 & 8.7 \\
(CLL) claws length (cm) & 1.7 & 3.1 & 2.3 & 0.5 & 21.3 \\
(TEL) tail length (cm) & 1.1 & 1.4 & 1.3 & 1.06 & 8.3 \\
\hline
\end{tabular}




\section{$\underline{\text { Results of comparative morfometrics analysis of white clawed crayfish samples }}$ from Neretva catchment area}

The biggest sample caught is male (location Neretvica) with total body length $8.9 \mathrm{~cm}$ and widest carapace $2.9 \mathrm{~cm}$. total body weight was $26 \mathrm{~g}$. The biggest female caught at the location Šištica with total body length of $7.9 \mathrm{~cm}$ and body weight $18 \mathrm{~g}$. Upon statistics analysis it was determined that body weight (W) has the highest variability coefficient and that this measuring feature varies the most. Determined coefficient was in range 14 to 35.28 .

Comparison in rostrum shape were performed (ROW and ROL) in samples from researched locations. Namely in specimens of $A$. pallipes from location Šištica it was determined that average rostrum length was $1.1 \mathrm{~cm}$ and width $0.7 \mathrm{~cm}$. In samples from Kraljuščica and Neretvica locations those values were between $0.8 \mathrm{~cm}$ for length and $0.7 \mathrm{~cm}$ for rostrum width. According to obtained values rostrum shape in samples from location Šištica was like isosceles triangle, while in other locations (Neretvica and Krajuščica) it was in shape of equilateral triangle. It is significant to emphasize that males are dominant in all 3 researched locations and selected samples (Fig. 4).

Differences were determined by analysis of comparative parameters in body weight in samples of same body length from analyzed river Neretva tributaries (Fig. 5); significant differences in body weight (the heaviest samples were from Neretvica 20 grams). Rostrum length was the smallest in samples from river Krasljuščice, and width from river Šištica which is also related to the highest value of rostrum length $(1,2 \mathrm{~cm})$.

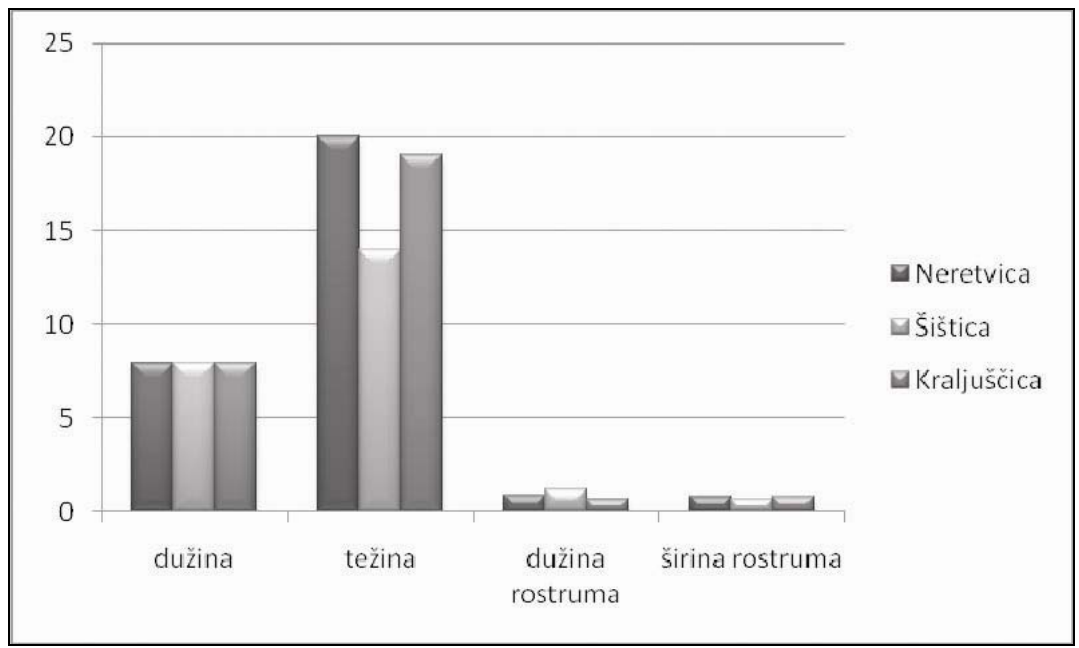

Figure 4 Gender comparison in samples of white clawerd srayfish from rivers Neretvica, Šištica and Kraljuščice

Grafikon 4. Odnos polova u uzorcima bjelonogog raka iz rijeke Neretvice, Šištice i Kraljuščice 


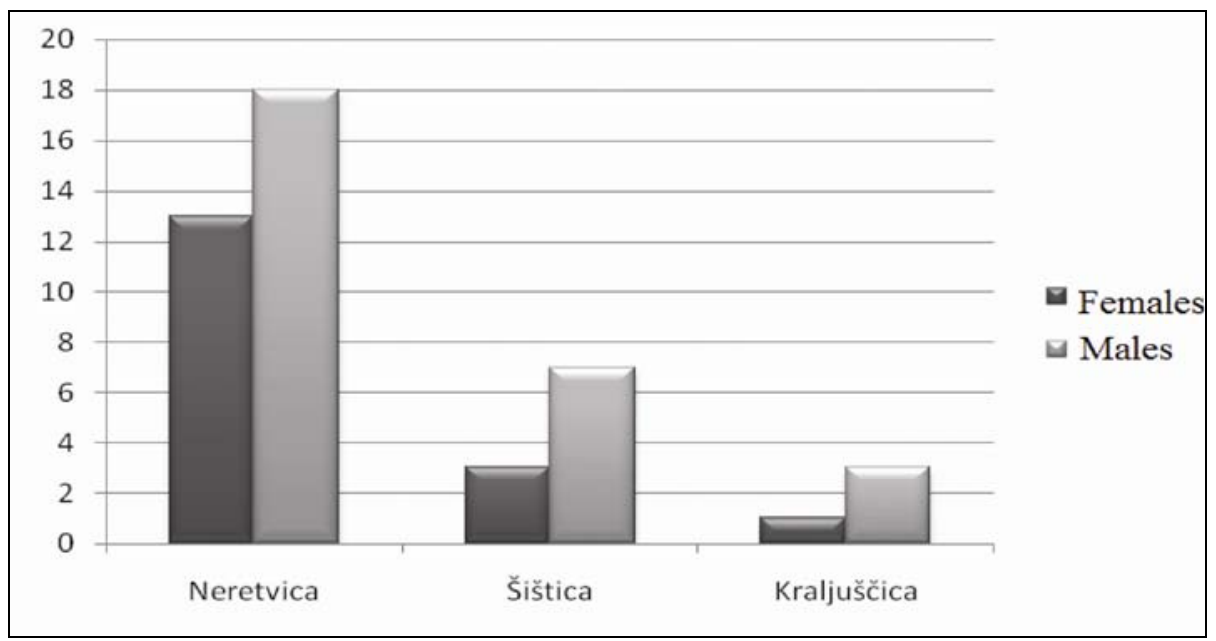

Figure 5. Values of body weight, rostrum length and width in samples of white clawed crayfish from Neretva River basin - with same body length $(7,9 \mathrm{~cm})$

Grafikon 5. Vrijednosti težine tijela, dužine i širine rostruma kod jedinki bjelonogog raka iz sliva rijeke Neretve, sa istom dužinom tijela $(7,9 \mathrm{~cm})$

In analysed samples body length was $6,4 \mathrm{~cm}$, highest value for body weight from river Šištice (16 grama), and the highest value of rostrum length 1,0 cm (Fig. 6).

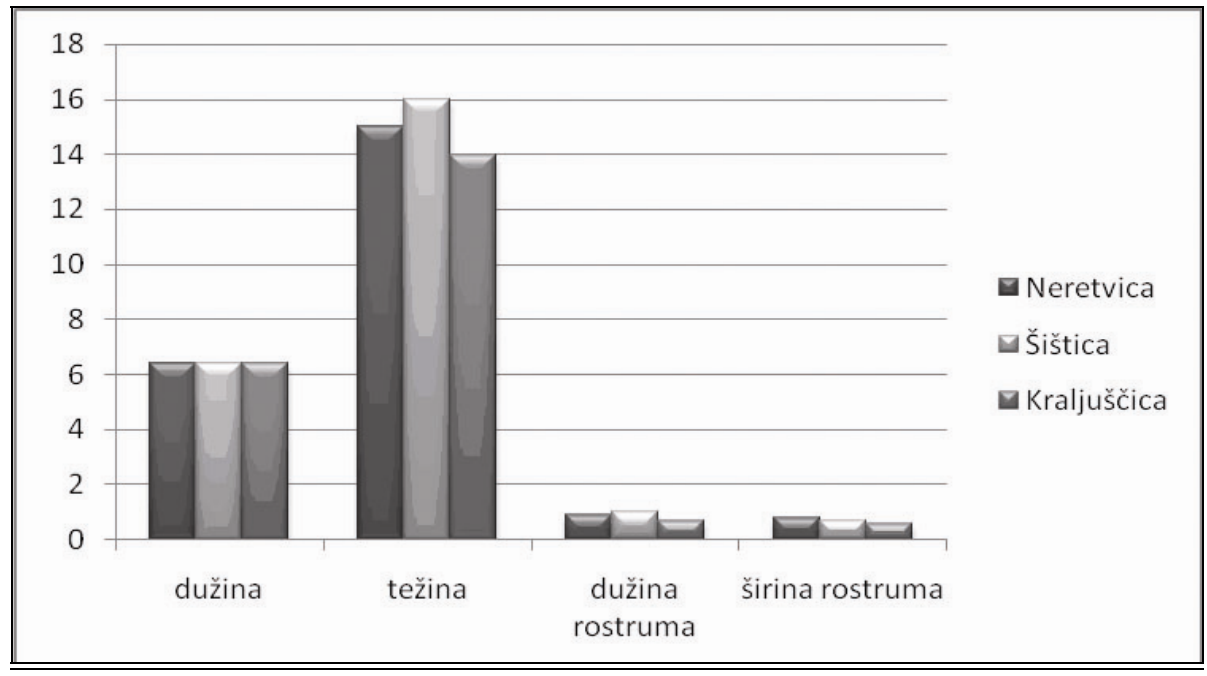

Figure 6. Values of body weight, rostrum length and width in samples from Neretva River basin, with same body length $(6,4 \mathrm{~cm})$

Grafikon 6. Vrijednosti težine tijela, dužine i širine rostruma kod jedinki bjelonogog raka iz sliva rijeke Neretve, sa istom dužinom tijela $(6,4 \mathrm{~cm})$ 


\section{Neretva river basin}

During statistics data processing certain correlation was determined between values of ob body length (TL) an carapace width (CPW). Regression analysis was performed in order of definition the existence of linear correlation between body length and carapace width.

Analysis established that there is significant linear correlation between body length and carapace width, with defined values $R^{2}-0.847$ and value $p-2.26151 \mathrm{E}-13$ (Fig. 7). The conclusion was that body length has been determined by carapace length and that samples with shorter bad have narrower carapace.

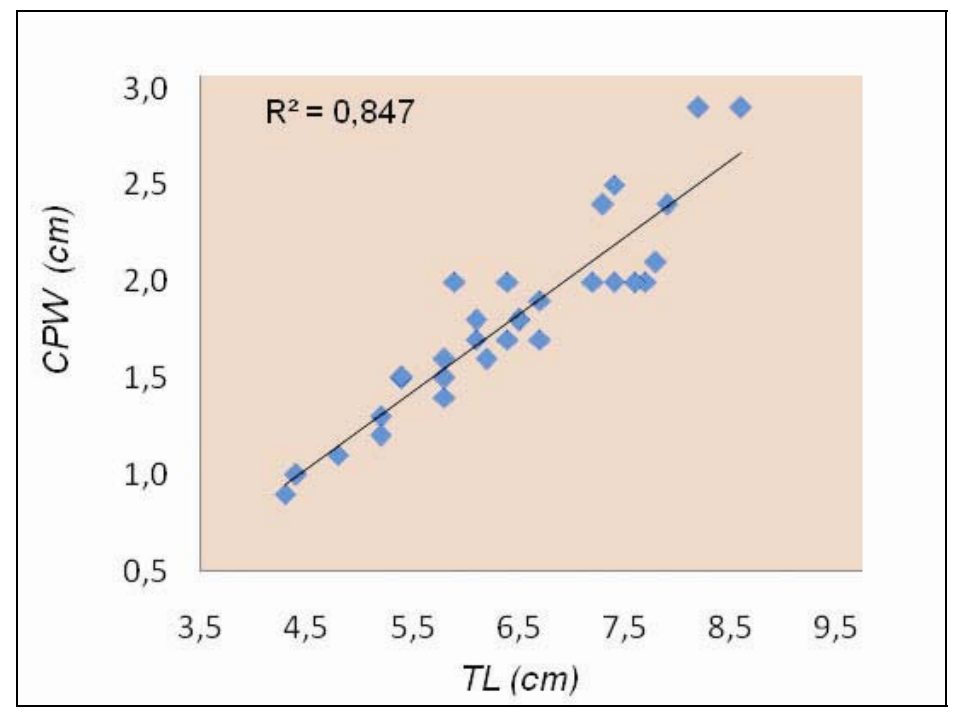

Figure 7. Linear regression of total body length (TL) and carapace width (CPW) of Austropotamobius pallipes from Neretva River basin

Grafikon 7. Značajna linearna povezanost ukupne dužine tijela (TL) i širine karapaksa (CPW) bjelonogog raka Austropotamobius pallipes iz sliva rijeke Neretve

It was determined that values of rostrum width and length in white clawed crayfish at the researched locations range between $0.5-1.2 \mathrm{~cm}$ and in width between $0.5-0.8 \mathrm{~cm}$. Rostrum shape presents one of the taxonomic features of this specie being defined by its length and width. Regression analysis we tried to determine if there is correlation between rostrum width (ROW) and head width (HEW). Obtained values $R^{2}-0.23$ and values $p-0.005412$ indicate that there is no significant correlation between head width and rostrum width. In other words that values of rostrum width are stabile and not depending on head width.

Regression analysis was conducted in terms of total body length (W) and claws length (CLL) where determined values were $R^{2}-0.588724611$ and values $p$ 3.59852E-06. Obtained values indicate that there is linear correlation between total body mass and claws length (Fig. 8.). One can expect that samples with higher values 
of body mass have bigger claws with exception when samples are in period of moulting when they reject their claws and new one grow.

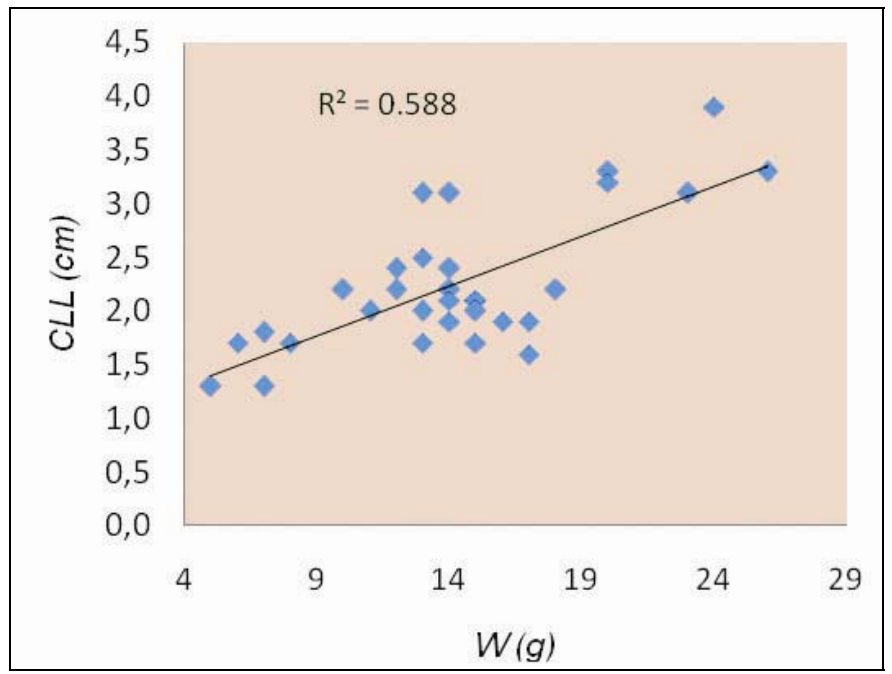

Figure 8. Linear regression between total body weight (W) and claws length (CLL) of Austropotamobius pallipes form Neretva River basin

Grafikon 8. Postojanje linearne povezanosti između ukupne težine tijela (W) i dužine kliješta (CLL) bjelonogog raka Austropotamobius pallipes iz sliva rijeke Neretve

\section{Condition index}

According to the values of total length, and weight, 2 condition indexes were calculated, and according to the comparison of obtained values it is obvious that specimens in 3 analyzed watercourses have favorable existence conditions (Tab.6). Relatively high values of both applied indexes were obtained for all samples (even tough different pattern was used in analyzed samples).

Table 6. Comparative illustration of condition index for samples of white clawed crayfish Austropotamobius pallipes from river Neretvica (31 samples), Šištica (10 samples) and Kraljuščica (4 samples)

Tabela 6. Uporedni prikaz vrijednosti kondicionog indeksa za jedinke bjelonogog raka Austropotamobius pallipes iz rijeke Neretvice (31 jedinka), Šištice (deset jedinki) i Kraljuščice (četiri jedinke)

\begin{tabular}{|c|c|c|c|c|c|c|}
\hline \multirow{2}{*}{ River } & \multicolumn{3}{|c|}{ FCF } & \multicolumn{3}{c|}{ CC } \\
\cline { 2 - 7 } & $\overline{\mathbf{x}}$ & $\mathbf{m i n}$ & $\mathbf{m a x}$ & $\overline{\mathbf{x}}$ & $\mathbf{m i n}$ & $\mathbf{m a x}$ \\
\hline Neretvica & 0.055 & 0,027 & 0,095 & 1.087 & 0,232 & 2,058 \\
Šištica & 0.043 & 0,024 & 0,070 & 0.843 & 0,038 & 0,053 \\
Kraljuščica & 0,043 & 0,566 & 1,263 & 1,010 & 0,860 & 1,140 \\
\hline
\end{tabular}




\section{DISCUSSION-Diskusija}

Use of morphological characteristics for identification of individual species of freshwater crayfish was developed in determination keys, but it is known that differences in crayfish morphology can manifest not only in different specie but in separated populations and al that as adaptation to the local habitat conditions (GRANDJEAN AND SOUTY-GROSSET, 2000, GRANDJEAN et.al. 2002, SINT et al., 2005).

Morfometric analysis was conducted for six measured characters where they were statistically processed. Calculated variability coefficients show which of the measured characters vary the most in natural populations of $A$. pallipes.

Morfometric analysis was conducted on samples caught on different locations of the Neretva catchment area: Neretvica, Kraljuščica and Šištica. Populations observed on researched locations are natural populations.

Major presence of males was noticed during terrain work. According to the research of white clawed crayfish in Boračko lake it was also noticed that there is more male than female samples (TROžIĆ-BOROVAC, 2011) but obtained data are corresponding with previously published papers (SINT et al., 2005).

Through character analysis it was determined that males and females mostly differ in terms of body weight, total body length and claws length, which has been confirmed by previously published data (MAGUIRE et al. 2004).

Comparative analysis was conducted of selected characters between males and females prior comparative analysis of morfometric characters from different locations in order to confirm the existence of gender diformism in white clawed crayfish, where males are always bigger than females (SOUTY-GROSSET et.al., 2006, TROŽIĆ-BOROVAC, 2012).

During research total 45 samples were caught, 17 females and 28 males.

Upon analysis it was observed that males and females have almost identical condition index which in females was 0.053 while in males it was 0.052 . White clawed crayfish prefers habitats with minor water streaming, sediment with a lot of fallen leafs of alder (Alnus glutinosa) and river silt in order to find covers. This specie is relatively resistant to the bad physical chemical water quality so it bears well with major oxygen and temperature oscillations with precondition that water hardiness is high. Research that has been conducted in Croatia indicates that there is no this crayfish specie in habitats with increased anthropogenic factors especially in industrial zones of rivers Cetina and Zrmanja (MAGUIRE et al. 2004).

Based on morfometric character analysis of the body length of all caught samples (from locations Neretvica Kraljuščica and Šištica) that was in range from 2.9 to $8.9 \mathrm{~cm}$ while body weight value was in range from 5 to $26 \mathrm{~g}$. Based on morfometric analysis of 30 samples of white clawed crayfish Austropotamobius pallipes from Boračko lake it was determined that variation of body length was in range from 8,5 to $12 \mathrm{~cm}$ while body weight was from 18.6 to $50.9 \mathrm{~g}$ (TROžIĆ-BOROVAC, 2011). 
At the location of Neretvica 12 females were found that were carrying fertilized eggs. It was determined that female in length of $7.1 \mathrm{~cm}$ carries 45 fertilized eggs between pleopods. Number of pleopod eggs depends on female size and values range from 25 eggs (for females of total length of $4.7 \mathrm{~cm}$ ) to 50 eggs (for females of total length of $8.1 \mathrm{~cm}$ ) (SOUTY-GROSSET et.all.2006), larger females carry more eggs (TAUGBøL et al. 1988). Samples of females were found whose total length was $23 \mathrm{~mm}$ and that were carrying eggs. (RHODES et al. 1982).

In riparian area of the researched locations largest number of samples were found since in riparian river basins water velocity is weaker or there is any at all. According to the preciously conducted research correlation between presence of the crayfish and water streaming where crayfish preferred streaming from $0-5 \mathrm{~m} / \mathrm{s}$ (STREISSL ET HODL, 2002).

Waters in which white clawed crayfish stay are primarily characterized with high concentrations of dissolved oxygen and small values of BPK5.

\section{CONCLUSIONS -Zaključci}

Based on comparative morfometric analysis of $A$. pallipes from Neretva catchment area following conclusions can be derived:

$\checkmark$ Explored specie mainly inhabits waters that belong to the category oligo up to $\beta$ - mesosaprobic waters that is I to II water category.

$\checkmark$ Gender diformism was determined based on comparative morfometric analysis of the characters of caught males and females of white clawed crayfish. Average length of male was $7.8 \mathrm{~cm}$ while in females it was $6.6 \mathrm{~cm}$.

$\checkmark$ There was larger number of males (28 samples) than females (17 samples).

$\checkmark$ Length of whole carapace in samples varies in range from 0.7 to $1.6 \mathrm{~cm}$

$\checkmark$ Linear correlation was determined between body length (TL) and claws length (CLL).

$\checkmark$ Defined values of condition index (FCF) are somewhat higher in males than in females

$\checkmark$ Differences between samples from different populations aren't visible but differences were noticed in length of rostrum and weight in same generation,

$\checkmark$ With regression analysis significant linear correlations between selected morfometric characteristics were defined. Linear correlation was determined between total body mss and claws length $\left(\mathrm{R}^{2}-0.588724611\right.$ and values $\mathrm{p}$ $2.359852 \mathrm{E}-06)$, as the body length and carapace width $\left(\mathrm{R}^{2}-0.847\right.$ and value $\mathrm{p}$ $2.26151 \mathrm{E}-13)$ 


\section{LITERATURE - Literatura}

AlbreCHT, H. (1983): Die Protastacidae n. fam., fossile Vorfahren der Flußkrebse? Neues Jahrbuch für Geologie und Paläontologie Monatshefte 1983: 5-15

Adegboye, D. (1981): The 'Crayfish Condition Factor' a tool in crayfish research. Freshw. Crayfish 5: 154-172.

ENTZ, G. (1914): Über die Flusskrebse Ungarns. Mathematische und Naturwissenschaftliche Berichte aus Ungarn. [1912] 30:67-127, 4 pls. (Leipzig).

GHeRARDI, F. (2002): Behaviour. U: Holdich, D. M. (ed.) Biology of freshwater crayfish. Blackwell Science, Oxford, 258-291

Grandjean, F., Frelon-Raimond, M., Souty-Grosset, C. (2002): Compilation of molecular data for the phylogeny of the genus Austropotamobius: one species or several? Knowledge-based management of European native crayfish, crayfish special Volume 4, (eds C. Souty-Grosset \& F. Grandjean). Bull. Fr. Pêche Piscic. $367,671-680$

HoBBs, H. H., JR. (1988): Crayfish distribution, adaptive radiation and evolution. U: Holdich, D. M. i Lowery, R. S. (eds.) Freshwater Crayfsih: Biology, Management and Exploitation. Croom Helm, London, 52-82.

HOLDICH, D. M. (2002): Biology of freshwater crayfish, Blackwell Science. Oxford

Karaman, S. (1929): Die Potamobiiden Jugoslviens. Glasnik zemaljskog muzeja u Bosni i Hercegovini XLI: 147-150

KARAMAN, M.S. (1961): Slatkovodni rakovi Jugoslavije. Ribarstvo Jugoslavije 3 (61): $1-33$

KARAmAn, M.S. (1962): Ein Beitrag zur Systematik Astacidae (Decapoda). Crustaceana 3: 173-191

Karaman, M.S. (1963): Studie der Astacidae (Crustacea, Decapoda) II. Teil. Hydrobiol. 22: 111-132

KARAmAN, M.S. (1976): Desetonogi rakovi-Decapoda. Prirodonaučen muzej na Makedonija, Skoplje, Fauna na Makedonija II.

LAURENT, P. J. (1988): Austropotamobius pallipes (Lereboullet, 1858) and A. torrentium, with observations on their interactions with other species in Europe. U Holdich, D. M. i Lowery, R. S. (eds.) Freshwater crayfish. University Press, Cambridge, 341-364

MaguiRe, I., GotTStein-MatoČEC, S. (2004): The Distribution pattern of freshwater crayfish in Croatia: Crustaceana 77 (1), 25-27

MaguiRE, I. (2002): Porodica Astacidae Latreille, 1802 u sjeverozapadnoj Hrvatskoj. Doktorska disertacija. Sveučilište u Zagrebu. Prirodoslovno-matematički fakultet, Zagreb. 
RHODES, C.P., \& HOLDICH D.M. (1982): Observations on the fecundity of the freshwater crayfish, Austropotamobius pallipes (Lereboullet) in the British Isles. Hydrobiologia 89, 231-236.

RICKER, W.E. (1975): computation and interpretation of biological statistics of fish populations.Bull.Fish.Res.Bd Can.191: 1-382.

RIEK, E. F. (1972): The phylogeny of the ParAstacidae Latreille, 1802 Huxley, 1879 (Crustacea: Astacoidea Latreille, 1802), and descriptions of a new genus of Australian freshwater crayfishes. Australian Journal of Zoology, 20: 369-389.

SkURdAL, J. TAUgBol, T. (2002): Astacus U: Holdich DM (ed.) Biology of freshwater crayfish. Bleckwell science, Oxford, 467-510.

SkURDAL, J. TAUGBOL, T. (2002) Astacus. In: Biology of freshwater crayfish: 467-510 (ed D.M.Holdich),Oxford, Blackwell Science

SNT, D., Dalla ViA, J., Füreder, L. (2005): Morphological variations in Astacus astacus (Linnaeus, 1758) L and Austropotamobius pallipes (Lereboullet) populations. In: European native crayfish in relation to land-use and habitat deterioration with a special focus on Austropotamobius torrentium CRAY-NET, Vol.4, (eds L. Füreder, C. Souty-Grosset) Bull. Fr. Pêche Piscic., 376-377, 637652ŠANDA R. AND PETRUSEK A. 2009. Distribution and diversity of crayfishes in the Adriatic drainage of Bosnia and Herzegovina. In: Kozák P. and Kouba A. (eds.), Abstract Book, Future of Native Crayfish in Europe, Regional European Crayfish Workshop, 7th-10th September 2009, Písek, 50. GRANDJEAN, F.\& SOUTY-GROSSET, C. (2000): Mitohondrial DNA variation and population genetic structure of the white-claved crayfish, Austropotamobius pallipes pallipes. Conservation Genetics.1:309-319.

Souty-Grosset, C., Holdich, D. M., NoËL, P. Y., Reynolds, J. D. Haffner, P. (2006): Atlas of Crayfish in Europe. Publications Scientifiques du Muséum national d'Historie naturelle, Paris, str. 187

StReISSL, F., HODL, V. (2002): Growth, morphometrics, size at maturity, sexual dimorphism and condition index of Austropotamobius torrentium Shrank. Hydrobiologia, 477, 201-208.

TAugbøl, T., SKuRdal, J., FJeLd, E. (1988): Maturity and fecundity of Astacus astacus (Linnaeus, 1758) females in Norway. Freshwater crayfish, 7: 107-114

TAYLOR, C. A. (2002): Taxonomy and conservation of native crayfish stocks. U: Holdich, D. M. (ed.) Biology of freshwater crayfish. Blackwell science. Oxford, 236-257.

TRONTELJ, P., MACHINO Y., SKET B. (2005): Phylogenetic and phylogeographic relationships in the crayfish genus Austropotamobius inferred from mitochondrial COI gene sequences. Molecular Phylogenetic and Evolution, 34: 212-226.

Trožıć-Borovac, S., DelJANIN, L., DAUTBAŠIĆ, M. (2007): Ecologycal and biosystematic characteristic of stone crayfish Austropotamobius torrentium 
(Shrank, 1804) from the Nohorevo brook. Work of the Faculty of Forestry, University of Sarajevo. No. 1, 2007 (30-55).

TROžIĆ-BorovaC, S. (2011): Freshwater crayfish in Bosnia and Herzegovina: the first report on their distribution. Knowl. Managt. Aquatic Ecosyst. 401, 26p1 -26p13

TROžIĆ-BOROVAC, S. (2012): Distribucija bjelonogog raka Austropotamobius pallipes (Lereboullet, 1858) species complex (Astacoidea Latreille, 1802; Astacidae Latreille, 1802) u Bosni i Hercegovine. Zbornik radova "Struktura i dinamika ekosistema Dinarida - stanje, mogućnosti i perspektive. Posebno izdanje CXLIX. Akademija nauka Bosne i Hercegovine. Srajevo, 23, 153-166

VARIŠčIć, M. (2009): Gornja Neretva (brošura). Udruženje za zaštitu okoline Konjic, Zeleni-Neretva.

VARIŠčć, M. (2011): Rijeka bez povratka: Ekologija i politike velikih brana. Udruženje za zaštitu okoline Zeleni-Neretva Konjic.

\section{SAŽETAK}

Izlov jedinki bjelonogog raka iz pritoka rijeke Neretve (Neretvica, Šištica i Kraljuščica) za potrebe analize morfometrijskih karaktera izvršen je u periodu maja do augusta 2011 godine. Analiza je obuhvatila parametre totalne dužine tijela, težine, dužine i širine rostruma, dužine i širine karapaksa, te dužinu i širinu kliješta. Najveća populacija utvrđena je u rijeci Neretvici (31 jedinka), a daleko najmanje jedinki konstatovano je u rijeci Kraljuščici (četiri). Izražena je dominacija mužjaka u ukupnom broju jedinki na sva tri istraživana vodotoka.

Totalna dužina tijela kretala se u dijapazonu od $2,9 \mathrm{~cm}$ do $8,9 \mathrm{~cm}$, a težina od $5 \mathrm{~g}$ do $26 \mathrm{~g}$. Statističkom analizom utvrđeno je da najveći koeficijent variranja ima težina tijela $(\mathrm{W})$, a razlike u težini tijela utvrđene su i kod jedinki iste dužine iz različitih vodotokova. Uporednom morfometrijskom analizom utvrđene su i razlike $u$ dužini i širini rostruma. Populacije bjelonogog raka iz Neretvice i Kraljuščice imaju isti oblik rostruma, dok je populacija iz Šštice sa različitim oblikom rostruma (jednokraki trokut). Primjenom linearne regresije utvrđen da jedinke kraćeg tijela imaju uži karapaks, te da jedinke sa većom težinom tijela imaju krupnija i veća kliješta. Širina glave nema nikakov utjecaja na širinu rostruma. Vrijednosti kondicionih indeksa kod mužjaka su nešto više nego kod ženki bjelonogog raka. Od istraživanih vodotoka, prema utvrđenoj brojnosti jedinki na površini od 100 metara, posebno se izdvaja rijeka Neretvica koja planirana za izgradnju hidrocentrala, te zahtijeva urgentne mjere $u$ zaštiti habitata populacije bjelonogog raka. 